\title{
Regulations for Returning Labour Migrants to Ukraine: International Background and National Limitations
}

\author{
Oleksandr Dluhopolskyi (iD https://orcid.org/0000-0002-2040-8762 \\ Sc.D., Professor at the Ternopil National Economic University, Ternopil, Ukraine \\ e-mail: dlugopolsky77@gmail.com
}

\section{Tetiana Zatonatska iD https://orcid.org/0000-0001-9197-0560 Sc.D., Professor at the Taras Shevchenko National University of Kyiv, Kyiv, Ukraine e-mail: tzatonat@ukr.net}

lelyzaveta Lvova (iD https://orcid.org/0000-0002-3381-3185 Ph.D., Assoc. Professor, ORIPA NAPA, Odessa, Ukraine e-mail: Ivovaliza@outlook.com

Yuriy Klapkiv (iD) https://orcid.org/0000-0002-9771-5357

Ph.D, Assoc. Professor at the University of Lodz, Faculty of Economics and Sociology, Insurance Department, Lodz, Poland, e-mail: jurij.klapkiv@uni.lodz.pl

\begin{abstract}
The current situation on the Ukrainian labour market is not only characterised by a high rate of unemployment, but also by low-wage jobs with relatively severe requirements from potential employers. The intensive labour migration from Ukraine is forced by factors such as lower standards of living when compared to the standards in neighbouring countries, the flexibility of changing the place of living and working, and the military crisis in the eastern parts of Ukraine, among others. The article is devoted to the policy on the return of labour migrants to Ukraine. The issues of the increasing number of asylum seekers arriving from Ukraine to other European countries from 2008 to 2017, and the analysis of the main migration trends and legal norms relevant to the migration issues have revealed the mismatch in directions of labour migration flows from Ukraine and boundary crossings by other migrants. By means of analysing the interaction between the rate of human development and
\end{abstract}


the efficiency of migrant integration policies, the authors have proposed several strategic tools to ease the return of the labour force to Ukraine, including the cessation of military actions, raising the level of economic progress, fighting corruption, expanding opportunities for small and medium-sized businesses, and solving environmental problems.

Keywords: citizenship, crisis, labour force, labour migration, migrant flows, migrant reintegration policy, social and economic policy

JEL: F22, F66, J4, J61

\section{Introduction}

Labour migration, which redistributes the labour force between countries and has a significant effect on the situation in those labour markets, is increasing. In the history of mankind, migration has always played a vital role in the progress of society. Nowadays, irregular migrant flows have reached such an extent that they encompass all continents and sectors of the population, and have become a crucial factor in the socio-economic transformations in the 21st century.

For example, if there were 173 million migrants in 2000, then by 2017 there were 258 million, i.e., one in thirty-five people in the world is a migrant, among whom one in sixteen is a refugee (International Migration Report).

The annual increase in the number of labour force migrants from Ukraine has led to economic, social and demographic losses. As a result, it requires a reaction from the public authorities (especially those focused on developing effective incentives for the ...incentives for the return of illegal labour migrants to Ukraine, ..., guaranteeing employment for locals and improving social security) and the raising of standards of living. International organisations that cover integration, inclusiveness, and informational and educational work with migrants also need to act. The regulatory framework of labour migration includes international legal norms and standards to protect migrant workers from violations of their rights, to protect refugees' rights, and to fight against human trafficking and the smuggling of migrants.

Foremost among the pillars are (United Nations Treaty Collection):

1. Migration for Employment Convention (No. 97, ILO, 1949).

2. Refugee Convention (UN, 1951).

3. International Covenant on Civil and Political Rights (UN, 1966).

4. Refugee Protocol (UN, 1967).

5. Migrations in Abusive Conditions and the Promotion of Equality of Opportunity and Treatment of Migrant Workers Convention (No. 143, ILO, 1977).

6. International Convention on the Protection of the Rights of All Migrant Workers and Members of Their Families (UN, 1990). 
7. Protocol to Prevent, Suppress and Punish Trafficking in Persons, Especially Women and Children (UN, 2000).

8. Protocol against the Smuggling of Migrants by Land, Sea and Air (UN, 2000).

9. Convention concerning Decent Work for Domestic Workers (No. 189, ILO, 2011).

The following international standards aim to eliminate the crucial factors that cause migration and to maximise the benefits of international migration for both the migrant workers and the countries actively involved in migration processes.

The texts of special conventions and protocols of international organisations shed light on the processes of the international labour force which are often linked to illegal and criminal activities. They result in enormous harm not only to the migrants themselves but also to the recipient and donor states.

The goal of this article is to present the most crucial problems facing the migratory movement of workers on an international scale.

\section{Literature review}

A number of publications show that migration can affect various socio-economic aspects of life, such as poverty and income (King 2002; Adams 2011), well-being (Nikolova, Graham 2015; Ivlevs et al. 2019), education and culture (Cortes 2015; Marekova et al. 2015), health (Gibson et al. 2011), social norms (Levitt 1998; Markowska-Manista 2016), corrupt behaviour (Ivlevs, King 2017), fertility (Beine et al. 2013), and civic and political engagement (Nikolova et al. 2017; Chauvet, Mercier 2014). The phenomenon of international migration has been a pressing issue lately, extending beyond the borders of a single continent. Today, migration is increasingly recognised as an important development tool for countries of origin.

Attitudes toward migrants have changed rapidly. Since the $19^{\text {th }}$ century, assumptions dominated that a migrant was someone poor and uneducated who had left their country in search of better economic conditions. This micro-level motivation was thoroughly researched within both the neoclassical and the new economics of migration theories. The dual market theory (Piore 1979) shifted the focus onto the demand for an immigrant physical labour force in industrialised societies and state-sponsored recruitment campaigns (Massey et al. 1993).

Towards the end of the $20^{\text {th }}$ century, migration started to become the norm, rather than the exception, with the notion of mobility as the embodiment of the post-modern condition. To the traditional economic motivation of labour migration, we add other rationales: excitement, experience, leisure, and seeing the world. Migration itself becomes a desirable act rather than an economic means to an end (King 2002). Hence, since the 1980s, transnational and mobility theories have come to the fore, with a number of intersecting approaches (sociology, economy, politics, social psychology, geography, and anthropology). 
The hardships generated by the transformation process in Ukraine were unique. However, Ukraine is an exceptional case study due to the scale, the duration, as well as the uncertainty and the instability caused by the fluctuating economic situation. Additionally, there is also the ubiquitous corruption which has flourished as one of the strategies and tactics of coping with the difficult material situation (Lapshyna 2014; Koshulko 2015), the decline in life expectancy, the long-term inability to provide for the basic needs (Abbott, Sapsford 2006), as well as migratory practices. In many ways, Ukraine is a unique case study. It is an example of a country which was once a prosperous and thriving republic but since the 1990s has undergone a triple transformation - the formation of a nation-state, the collapse of the non-market command economy and the introduction of elements of a market economy (including employment insecurity and market prices) and the collapse of a social structure (Abbott, Sapsford 2006). All of these have resulted, on the one hand, in the decline of the standard and quality of life of many individuals, families and households, and on the other hand, in massive migration outflows. Initially, migration was largely in the pursuit of paid work as an ad hoc response to economic uncertainty. However, with the prolonged instability and bleak prospect of constructive changes, migration has become a permanent tactic of almost half of the population who wish to work or live abroad and experience a better quality of life.

\section{International and individual domestic legal safeguards of labour migration - lessons from Ukraine}

Table 1 shows the change in the number of international migrants and refugees during the period 1970-2017, in terms of destination areas. If the total number of international migrants in the world during this period has more than tripled, then in Africa - it is 1.8 times, in Asia - 2.3, in Latin America - 1.6, in North America - 4.3, and Europe -3.5 times. The problem of refugees has become particularly aggravated, as their number has grown more than 4.5 times globally over 47 years (in Africa - 4 times, in Asia - 6.6 times, and in Europe and the former USSR - 2.5 times). The percentage of refugees in the total number of international migrants has increased from $5.3 \%$ to $8 \%$.

With respect to Ukraine, nowadays, labour migration not only reduces the supply of labour in the domestic labour market, but it also reduces the quality, since most of the motivated and creative workers have fled.

Social and economic factors provoke the departure of labour force (especially from the western parts of Ukraine), e while the work in foreign countries is often perceived as real "earnings" that bring real incomes in freely convertible currency. This is even the case when the cost of living abroad (in cash equivalent), health, long-term separation from the family (in non-monetary equivalent) and the net gain from working abroad compared to working in Ukraine may be zero. 
Regulations for Returning Labour Migrants to Ukraine...

\begin{tabular}{|c|c|c|c|c|c|c|c|c|c|c|}
\hline \multirow{6}{*}{ 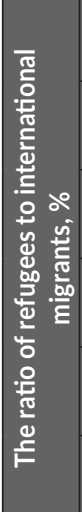 } & हे & $\begin{array}{l}\circ \\
\infty \\
\infty\end{array}$ & $\stackrel{\nabla}{-}$ & $\stackrel{-}{\stackrel{-}{A}}$ & $\begin{array}{l}2 \\
\stackrel{2}{-}\end{array}$ & $\begin{array}{l}0 \\
\stackrel{1}{-}\end{array}$ & $\stackrel{\sim}{\sim}$ & \begin{tabular}{c|}
$\infty$ \\
0 \\
0
\end{tabular} & $\hat{o}$ & $\stackrel{\leftrightarrow}{\rightarrow}$ \\
\hline & 을 & oे & $\stackrel{n}{\rightarrow}$ & $\underset{⿱}{\stackrel{\sim}{\sim}}$ & $\begin{array}{l}m \\
\dot{\sim}\end{array}$ & $\begin{array}{l}0 \\
0 \\
0 \\
-1\end{array}$ & $\stackrel{\circ}{+}$ & \begin{tabular}{c|}
$\infty$ \\
0 \\
0
\end{tabular} & $\stackrel{\text { ก }}{0}$ & $\stackrel{N}{N}$ \\
\hline & ঃ & $\approx$ & $\stackrel{\mathrm{v}}{\mathrm{v}}$ & $\begin{array}{l}n \\
\infty \\
\infty \\
\rightarrow \\
\end{array}$ & 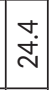 & $\mid \begin{array}{l}0 \\
0 \\
\stackrel{0}{-1}\end{array}$ & $\hat{o}$ & $\begin{array}{l}0 \\
\stackrel{\sim}{-}\end{array}$ & $\stackrel{\text { }}{\sim}$ & $\stackrel{-}{\forall}$ \\
\hline & 음 & $\stackrel{\overbrace{}}{\exists}$ & $\stackrel{\sim}{\mathrm{N}}$ & O & 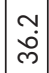 & ¿̊. & î. & $\vec{\sim}$ & $\stackrel{m}{i}$ & $\hat{i}$ \\
\hline & $\begin{array}{l}\text { ळ } \\
\text { ‡े }\end{array}$ & $\stackrel{0}{\circ}$ & $\vec{m}$ & 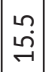 & 吕 & $\begin{array}{l}m \\
\stackrel{m}{g}\end{array}$ & $\stackrel{\Delta}{\mathrm{i}}$ & $\stackrel{\circ}{\circ}$ & $\underset{\infty}{+}$ & $\vec{\sim}$ \\
\hline & 尽 & $\stackrel{m}{i}$ & $\vec{m}$ & $\stackrel{m}{\sim}$ & - & $\vec{r}$ & $\stackrel{\leftrightarrow}{\rightarrow}$ & $\begin{array}{l}\stackrel{\circ}{\forall} \\
\dot{\forall}\end{array}$ & $\stackrel{n}{\sim}$ & $\widehat{\sim}$ \\
\hline & 로 & $\begin{array}{l}\circ \\
\stackrel{2}{a}\end{array}$ & $\stackrel{\sigma}{\vec{i}}$ & 茨 & $\stackrel{\circ}{+}$ & $\begin{array}{l}\tilde{n} \\
\mathfrak{m} \\
\sim\end{array}$ & $\stackrel{0}{0}$ & $\stackrel{\Delta}{\circ}$ & $\stackrel{\circ}{\circ}$ & זִ \\
\hline 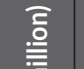 & 윰 & : & $\stackrel{\circ}{\mathrm{i}}$ & $\begin{array}{l}m \\
\stackrel{m}{\vec{q}} \\
\end{array}$ & 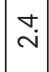 & $\begin{array}{l}n \\
0 \\
0 \\
0\end{array}$ & $\stackrel{0}{0}$ & $\stackrel{\forall}{\circ}$ & $\stackrel{\circ}{\circ}$ & م- \\
\hline $\begin{array}{l}\bar{y} \\
\mathbb{J}\end{array}$ & ஓి & 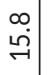 & 이 & $\begin{array}{l}\infty \\
\stackrel{i}{\sim}\end{array}$ & $\stackrel{0}{\dot{m}}$ & $\stackrel{N}{\alpha}$ & $\stackrel{\nabla}{0}$ & $\begin{array}{l}0 \\
0\end{array}$ & ন্ & $\stackrel{m}{i}$ \\
\hline$\frac{\varrho}{\underline{2}}$ & 을 & $\begin{array}{l}\infty \\
\infty \\
\rightarrow \\
\rightarrow\end{array}$ & $\stackrel{\circ}{i}$ & $\begin{array}{l}0 \\
0 \\
\dot{\sigma}\end{array}$ & $\begin{array}{l}0 \\
\dot{H} \\
\end{array}$ & $\stackrel{\sigma}{\sigma}$ & $\stackrel{\sim}{\sim}$ & $\begin{array}{l}0 \\
0\end{array}$ & 뭉 & $\stackrel{m}{\rightarrow}$ \\
\hline 忢 & @ & $\stackrel{2}{\sigma}$ & $\stackrel{n}{\rightarrow}$ & $\stackrel{-1}{\infty}$ & $\begin{array}{l}0 \\
\dot{c}\end{array}$ & $\stackrel{m}{\sim}$ & 뭉 & O०. & $\stackrel{3}{\circ}$ & 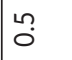 \\
\hline & 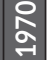 & $\stackrel{m}{*}$ & $\underset{i}{\sim}$ & $\stackrel{-1}{\dot{m}}$ & $\stackrel{\circ}{\rightarrow}$ & 이 & 궁 & 告 & $\stackrel{\circ}{\circ}$ & $\stackrel{\circ}{\circ}$ \\
\hline 름 & 로 & 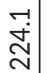 & $\begin{array}{l}\infty \\
\infty \\
\stackrel{\infty}{\rightarrow} \\
\rightarrow\end{array}$ & $\begin{array}{l}0 \\
\stackrel{1}{0} \\
\infty\end{array}$ & $\begin{array}{l}0 \\
0 \\
0 \\
-1\end{array}$ & $\begin{array}{l}\sigma \\
\vec{i} \\
\end{array}$ & $\begin{array}{l}\infty \\
\infty\end{array}$ & 年 & $\stackrel{-1}{\infty}$ & 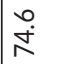 \\
\hline & 웅 & $\begin{array}{l}\text { フे. } \\
\text { ठें }\end{array}$ & $\begin{array}{l}0 \\
\stackrel{\rho}{\oplus} \\
\stackrel{\rightarrow}{-1}\end{array}$ & $\begin{array}{l}\infty \\
\stackrel{i}{\wedge} \\
\end{array}$ & $\underset{\forall}{\stackrel{+}{+}}$ & 苞 & $\stackrel{\infty}{\sim}$ & $\begin{array}{l}\infty \\
0 \\
i \\
i n\end{array}$ & $\vec{\pi}$ & 产 \\
\hline 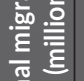 & ঃి & 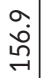 & $\begin{array}{l}+ \\
\dot{0} \\
\dot{\sigma}\end{array}$ & $\begin{array}{l}n \\
\stackrel{n}{0} \\
\llcorner\end{array}$ & 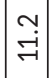 & $\overrightarrow{\dot{\sigma}}$ & ִָ & 官. & N & 울 \\
\hline 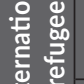 & 육 & 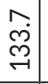 & $\begin{array}{l}\stackrel{+}{\circ} \\
\infty\end{array}$ & 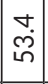 & 光 & $\begin{array}{l}\mathfrak{N} \\
\infty \\
m\end{array}$ & 궁 & 虽 & $\stackrel{\circ}{\sim}$ & 字 \\
\hline & $\begin{array}{l}\stackrel{8}{\circ} \\
\stackrel{-}{-}\end{array}$ & ํ. & ָ̃ & $\begin{array}{l}O \\
\dot{f} \\
\dot{f}\end{array}$ & $\begin{array}{l}n \\
0 \\
0 \\
\stackrel{9}{1}\end{array}$ & $\begin{array}{l}0 \\
\stackrel{0}{0} \\
\stackrel{0}{0}\end{array}$ & ○. & 㐫. & $\stackrel{\oplus}{\grave{m}}$ & $\stackrel{a}{\dot{d}}$ \\
\hline 䓂 & م̊ & $\stackrel{\Upsilon}{\nwarrow}$ & 공 & 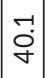 & $\begin{array}{l}0 \\
\infty \\
\infty\end{array}$ & 光 & L & $\begin{array}{l}n \\
\\
\end{array}$ & $\stackrel{\circ}{\circ}$ & $\stackrel{\sim}{i}$ \\
\hline 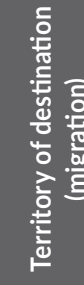 & & 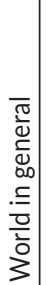 & 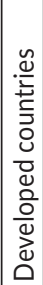 & 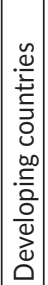 & 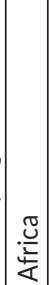 & $\frac{. \pi}{\frac{\pi}{2}}$ & 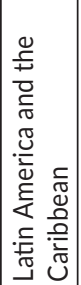 & 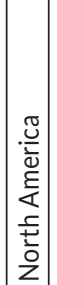 & 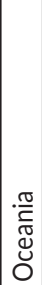 & 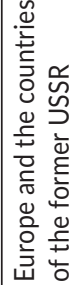 \\
\hline
\end{tabular}


The new flow of migrants from Ukraine is taking place in conditions of a hybrid war and Ukrainian crises caused by the aggression of the Russian Federation. An additional, comprehensive account of all negative factors related to labour migration should include such problems as low financial literacy, word of mouth (WOM) regarding the prospects of expedient employment abroad, distrust of state bodies, and transparent contests for high-paying positions on competitive terms and long periods of employment due to bribes and nepotism.

As the International Migration Report (UN 2017) states, critical issues include the spread of illegal migration; non-compliance with the laws and rules of entry into the territory of the country; illegal hiring of migrant workers; expanding the activities of organised crime groups for the smuggling of migrants; inhuman attitude towards employees; human trafficking and labour slavery; a threat to migrants' lives or safety; improper protection of the rights of migrant workers; and impeding the unification of families of migrant workers living in the territory of a given country on legal grounds, etc.

Ukraine is an extremely rich country whose wealth lies not only in the diversity of minerals, its geographic location, and the opportunities for the development of many spheres but also in the fact that human capital can be called the real wealth of Ukraine. However, the periodically recurring crises, the unstable economic system, corruption, the oligarchic model of development, and the military actions that lasted several years in the eastern parts of the country, have played a key role in reducing the population of Ukraine. Each year the population of Ukraine decreases - from 51.9 million in 1994 to 43.9 in 2018. The number of migrants (net) in 2010 was determined to be $+53,900$, but in 2015, it was $-40,000$, and in 2018 it amounted to $-20,000$ (Ukraine population 2018). In general, over the 27 years of Ukraine's independent statehood, more than 8 million people between the ages of 23 and 40 left the country in search of a better life (Мінсоцполітики 2018).

From the $19^{\text {th }}$ century to the present, Ukraine (in all its state forms) survived several waves of mass emigration due to overpopulation, land shortage, the threat to life, or poverty. Firstly, the country was left mainly by the intelligentsia and the upper classes. However, today, it is the working professions (builders, painters, versatile people), as well as a smaller percentage of intellectuals (programmers, scientists, engineers, employees of the budgetary sphere public sector employees) who are eager to leave. In 2017, around $\$ 9.3$ billion was transferred to Ukraine by labour migrants; in 2018 National Bank of Ukraine predicts transfers will grow to $\$ 11.3$ billion (Національний банк України 2018).

Labour migration has a multi-dimensional impact on Ukrainian society. On the one hand, it reduces labour market tensions, promotes the welfare of many families, and is the source of foreign exchange earnings and intangible transfers of new knowledge and experience that can contribute to the development of the state. On the other hand, it causes a shortage of workers in some sectors and regions, and negatively affects family relationships, the upbringing of children, and birth rates. The earnings 
of migrants, mainly aimed at consumption, provoke price increases, inflation, and the growth of imports (Strategy of the State Migration Policy of Ukraine 2018).

The lack of prospects for professional growth, unfavourable conditions for small and medium-sized businesses, high levels of corruption in all spheres of activity, and the unstable political situation contribute to the increase in labour migration. 35\% of the economically active population of Ukraine are, in one way or another, considering the possibility of finding a job abroad (Скільки українців хочуть виїхати за кордон 2018). The high level of labour migration is mainly provided at the expense of the western and central regions of the country.

According to the International Organisation for Migration (IOM) (2018), Ukrainian labour migrants tend to go to Poland (25\%), the Russian Federation (19.2\%), the Czech Republic (18.3\%), Italy (15.7\%), Germany (3.2\%), and Portugal (2.7\%), as well as many other European countries. Ukrainians received more permanent residence permits in European Union countries than any other nation in 2017, with 661,874 gaining the right to settle in an EU country (Migration in Ukraine 2018). The vast majority of these permits were issued in Poland - circular migration (87\%). In general, a large number of migrants aged 30-40 are interested in long-term migration, while those who are 45+ are mainly interested in short-term migration. $37 \%$ of emigrants have graduated from higher education but are forced to work outside their profession in low-skilled work in the host country.

According to the Migration as an Enabler of Development in Ukraine (2016) study conducted published by the IOM, the structure of migrants from Ukraine is dominated by men, most of whom are aged 30-44 (over 40\%), and the majority of whom originate in the west of the country. A study by the European Asylum Support Office (2018) has shown that the number of Ukrainians who want to leave the country has increased 14 times over the past six years. Today, Ukraine is in the top ten countries with the largest number of applications for asylum in the EU.

According to the data in Table 2, starting in 2008, the number of asylum seekers from Ukraine has increased dramatically in countries such as Spain, Italy, Germany and Poland. The largest percentage of Ukrainian asylum seekers in 2017 was recorded in the Czech Republic - 34.1\% of the total number of applications made by Ukrainians were submitted in this country. Spain was also popular (16.3\% of Ukrainian applications were submitted there), Poland (10.6\%), and Portugal (9.5\%). A fairly low percentage of Ukrainians sought refuge in Italy and Sweden $(2.1 \%$ of the total number of applications), the Netherlands (1.6\%), Denmark (1.5\%), Austria and Belgium $(0.8 \%)$, France $(0.7 \%)$, Germany, Switzerland and the United Kingdom $(0.3 \%)$, and Greece $(0.2 \%)$. However, the number of Ukrainians in the total number of asylum seekers in 2016 was only $0.9 \%$. Trends in 2012 were almost the same: the Czech Republic $-23.1 \%$ of Ukrainian applications; Sweden, France, Germany $-0.2 \%$. The number of Ukrainians in the total number of asylum seekers was only $0.3 \%$. Trends for 2008 : the Czech Republic (19.3\%), Austria (1.1\%), Belgium, Poland (0.4\%), Greece (0.3\%), and France and Sweden (0.2\%). The number of Ukrainians in the total number of asylum seekers also amounted to $0.3 \%$. 
Oleksandr Dluhopolskyi, Tetiana Zatonatska, lelyzaveta Lvova, Yuriy Klapkiv

Table 2. Asylum applications in Europe, annual total

\begin{tabular}{|l|r|r|r|r|r|r|}
\hline \multirow{2}{*}{ Country } & \multicolumn{2}{c|}{2008} & \multicolumn{2}{c|}{2012} & \multicolumn{2}{c|}{2017} \\
\cline { 2 - 7 } & Total & Ukrainians & Total & Ukrainians & \multicolumn{1}{c|}{ Total } & Ukrainians \\
\hline Spain & 4515 & 5 & 2565 & 20 & 15,755 & 2570 \\
\hline Italy & 30,145 & 15 & 17,350 & 35 & 122,960 & 2570 \\
\hline Germany & 26,945 & 45 & 77,650 & 135 & 745,265 & 2490 \\
\hline Poland & 8515 & 40 & 10,755 & 70 & 12,305 & 1300 \\
\hline France & 41,845 & 75 & 61,455 & 145 & 84,270 & 660 \\
\hline Sweden & 24,875 & 55 & 43,945 & 130 & 28,860 & 615 \\
\hline Czech Republic & 1,650 & 320 & 755 & 175 & 1,480 & 505 \\
\hline Austria & 12,750 & 140 & 17,450 & 80 & 42,285 & 375 \\
\hline Netherlands & 15,255 & 20 & 13,100 & 30 & 20,945 & 340 \\
\hline Belgium & 15,940 & 65 & 28,285 & 90 & 18,325 & 155 \\
\hline Portugal & 160 & NA & 295 & 5 & 1,465 & 140 \\
\hline United Kingdom & NA & NA & 28,895 & 60 & 38,870 & 130 \\
\hline Greece & 19,855 & 55 & 9,575 & 45 & 51,110 & 120 \\
\hline Switzerland & 16,605 & 30 & 28,640 & 30 & 27,195 & 95 \\
\hline Denmark & 2,375 & 5 & 6,075 & 15 & 6,195 & 95 \\
\hline Total & 257,460 & 975 & 374,620 & 1165 & $1,292,280$ & 12,610 \\
\hline
\end{tabular}

Source: Migration Policy Institute, 2018.

Of the total number of asylum seekers, immigrants from Ukraine in 2017 submitted the most applications to the relevant institutions of Italy and Spain $(20.4 \%$ of applications), Germany (19.7\%), Poland (10.3\%), France (5.2\%), Sweden (4.8\%), and the Czech Republic (4\%). In 2012, the situation was slightly different: 15\% of Ukrainian applications went to the Czech Republic, $12.4 \%$ - to France, $11.6 \%$ - to Germany, $11.2 \%$ - to Sweden, 7.7\% - to Belgium, and 6.8\% - to Austria. In 2008, the situation was as follows: $32.8 \%$ of applications went to the Czech Republic, $14.2 \%$ - to Austria, $7.7 \%$ - to France, $6.7 \%$ - to Belgium, $5.6 \%$ - to Sweden.

Nevertheless, if we analyse the trends of the change in the total number of asylum seekers in Europe, the situation looks different. In 2017, the largest number of applications for refugee status was submitted to Germany (57.6\%), Italy (9.5\%), France (6.5\%), Greece (3.9\%), Austria (3.2\%), Great Britain (3\%), and Sweden (2.2\%). The situation in 2012 was as follows: $20.7 \%$ - to Germany, $16.4 \%$ - to France, $11.7 \%$ - to Sweden, $7.7 \%$ - to Great Britain, 7.6\% - to Switzerland, 7.5\% - to Belgium, and 4.6\% - to Italy and Austria. In 2008, the situation was as follows: $16.2 \%$ - to France, $11.7 \%$ - to Italy, $10.5 \%$ - to Germany, $9.6 \%$ - to Sweden, $7.7 \%$ - to Greece, and $6.4 \%$ - to Switzerland.

According to the data in Table 3, during the period 2008-2017, the number of asylum seekers from Afghanistan, Syria, Pakistan and Eritrea increased at a higher pace. The problem is that the majority of these migrants who chose EU countries as their countries of future residence predominantly rely on social welfare policies and integration rather than the specifics of labour regulations. 
The main statistical findings show that first-time asylum applicants were down by $25 \%$ in the first quarter of 2018 compared with the same quarter of 2017 (Fig. 1). In the first quarter of 2018, 37\% of first instance decisions on asylum applications taken by the EU Member States were positive.

Table 3. Top-10 countries of origin in all asylum seekers

\begin{tabular}{|c|c|c|c|c|c|c|c|}
\hline \multirow{2}{*}{ Country } & \multicolumn{2}{|c|}{2008} & \multicolumn{2}{|c|}{2012} & \multicolumn{2}{|c|}{2017} & \multirow{2}{*}{$\begin{array}{l}\text { Total } \\
\text { growth }\end{array}$} \\
\hline & number & $\%$ & number & $\%$ & number & $\%$ & \\
\hline Syria & NA & NA & 25,625 & 6.8 & 341,980 & 26.5 & 13.3 \\
\hline Afghanistan & 11,865 & 4.6 & 30,350 & 8.1 & 190,195 & 14.7 & 16.0 \\
\hline Iraq & 32,210 & 12.5 & 13,835 & 3.7 & 131,590 & 10.2 & 4.1 \\
\hline Pakistan & 10,450 & 4.1 & 20,040 & 5.3 & 50,015 & 3.8 & 4.8 \\
\hline Nigeria & 12,235 & 4.7 & NA & $\ldots$ & 48,810 & 3.7 & 3.9 \\
\hline Iran & NA & $\ldots$ & 14,385 & 3.8 & 42,010 & 3.2 & 2.9 \\
\hline Eritrea & 9,525 & 3.7 & 11,925 & 3.2 & 40,205 & 3.1 & 4.2 \\
\hline Albania & NA & $\ldots$ & NA & $\ldots$ & 32,790 & 2.5 & $\ldots$ \\
\hline Russia & 22,240 & 8.6 & 24,930 & 6.6 & 27,760 & 2.1 & 1.2 \\
\hline Somalia & 19,355 & 7.5 & 17,275 & 4.6 & 21,755 & 1.7 & 1.1 \\
\hline Serbia & 15,655 & 6.1 & 21,005 & 5.6 & NA & $\ldots$ & 1.3 \\
\hline Turkey & 7,690 & 3.0 & NA & $\ldots$ & NA & $\ldots$ & $\ldots$ \\
\hline All & 257,460 & 100 & 374,620 & 100 & $1,292,280$ & 100 & $\ldots$ \\
\hline
\end{tabular}

Source: Asylum statistics, 2018.

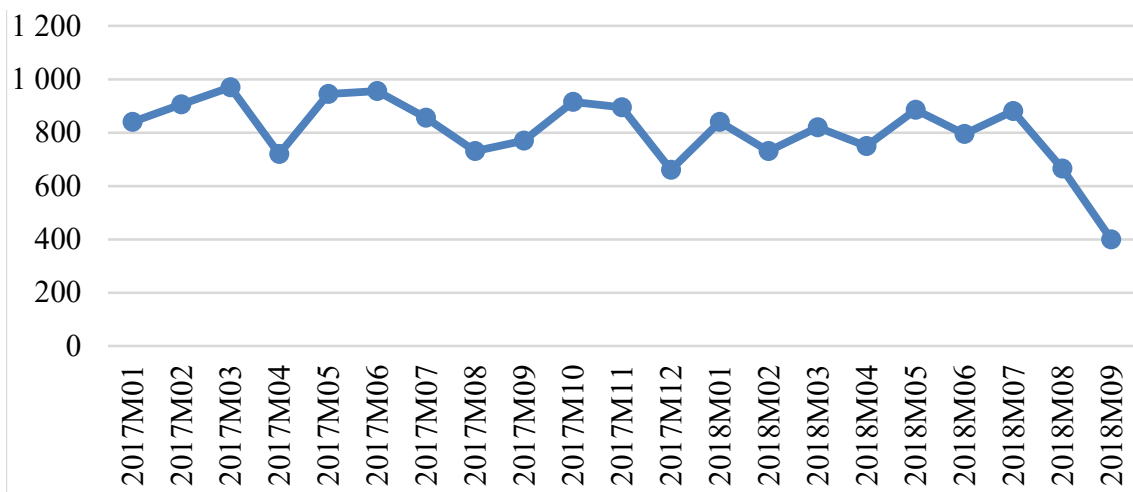

Figure 1. Asylum and first-time asylum applicants, EU-28

Source: Eurostat, 2018. 


\section{Socio-economic dimensions of migrant integration policy}

There is a dearth of scientific works analysing migration problems in the scope of the interaction between the rate of human development and the effectiveness of migrant integration policies.

We will try to estimate the link between the level of human development in 38 countries, calculated using the Human Development Index (HDI) indicator, with the rate of the Migrant Integration Policy Index (MIPEX). In 2004, a special methodology for assessing the policy of migrant integration was developed for the countries of the European Union based on the assessment of the legislation of those countries, according to its compliance with the Council of Europe Conventions and the European Community Directives concerning the legal status of migrants. This methodology was called the "MIPEX Integration Index".

The only evaluating integration policy criterion makes it possible to use the MIPEX index to compare countries, and it also gives an opportunity to see the areas of integration policy that require the elaboration of a legislative framework. The assessment of the legislation of the countries in the area of their integration policy was conducted in 2004, 2007, 2010 and 2015, and a ranking of countries was performed each time. In 2010, it included 33 states: 25 EU countries plus Canada, Norway, Switzerland, Bulgaria, Romania, the USA, Australia and Japan. In 2015, it had increased to include 38 states.

The MIPEX index is "multidimensional" because it analyses integration policy in seven directions at once: access to the labour market; reunion with the family; education; long-term stay; participation in the political life of the country; prospects for obtaining citizenship; and protection against discrimination. Each of the seven directions is divided into sublevels, most often the level of eligibility, the level of integration, and the level of security. It should be noted that compared to 2010, in 2015, the policy of migrants had become more stringent and countries in the rating MIPEX had reduced their positions. Thus, the top ten countries for integrating migrants were Sweden, Portugal, New Zealand, Finland, Norway, Canada, Belgium, Australia, the USA, and Germany (Migrant Integration Policy Index 2015).

According to the methodology for constructing the MIPEX index, in the ranking of lead countries, where "integration" is interpreted as adhering to the principle of equal opportunities, the gap between the rights and opportunities of citizens and immigrants is minimal. On the other hand, the position in the rating does not make it possible to judge how much more difficult it is for an immigrant to integrate into one country compared to another. For example, in the overall MIPEX rating, the Netherlands and Spain have the same overall score (60\%), but this does not mean that these countries are equally open to immigrants. The Netherlands, for example, is considerably far below Spain in terms of "long-term stay" and "access to the labour market"; conversely, it surpasses Spain in the direction of "protection against discrimination". 


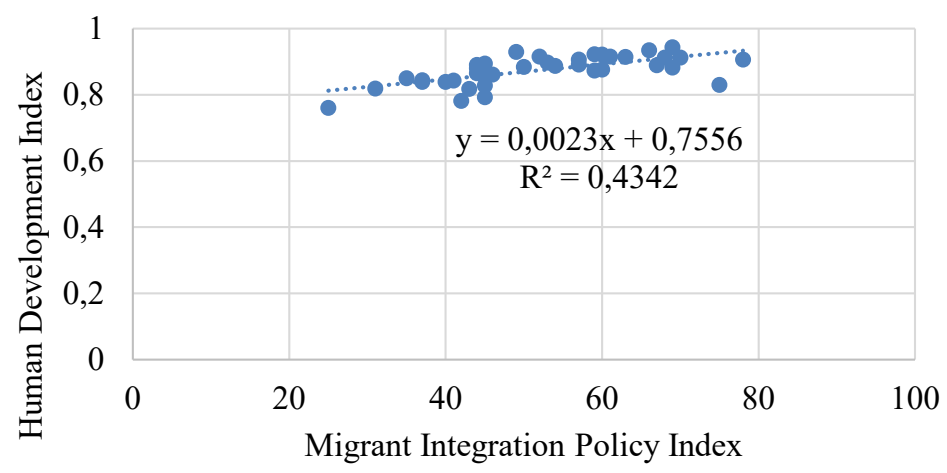

Figure 2. The connection between MIPEX and HDI

Source: based on Human Development Report (2017) and the Migrant Integration Policy Index (2015).

Analysis of data on the level of development of human capital based on the HDI and MIPEX indicators allows us to construct a correlation and regression model, which is presented in Fig. 2. The vertical axis contains the Indicator of Human Development Index; the horizontal axis is the MIPEX indicator. As can be seen from the data in Fig. 2, there is a direct correlation between the level of HDI (human development) and the quality of the policy of migrant integration. Although the density of communication is average $\left(R^{2}=0.4342\right)$, it is clear that the quality of the migrant integration contributes to the progress of human development, in educational settings and in improving the welfare of the migrants, the length of their time in the host country, and the reduction of the level of property inequality between citizens of that or another host country and the migrants.

\section{Labour migration of Ukraine: the phone calls experiment}

Analysing the official statistics (State Statistics Service of Ukraine 2018), it is possible to claim that over $20 \%$ of the able-bodied population of Ukraine has experience in working abroad, and 70,000 students study in the EU. Official data also indicates the two key countries of residence and work of labour migrants from Ukraine - Poland and Russia, which covers about $80 \%$ of the total flows of short-term and long-term Ukrainian migrant workers (Migration in Ukraine 2018). In terms of long-term contracts, Ukrainians work mainly in the building sector (45\%), manufacturing (12\%) and domestic services (12\%), while in the short-term - in the building sector (37\%) and agriculture (11\%).

However, we will try to estimate the extent of labour migration based on the analysis of the number of phone calls from Ukraine to the countries of the world on the night of December 31,2017, to January 1st, 2018, when there were preferential tariffs for calls abroad on the Vodafone Ukraine network. According to the data in Table 4, on New Year's Eve, $68 \%$ of Ukrainians made calls to the Russian Federation, almost $10 \%$ to Poland, and almost $6 \%$ to Italy. 
Oleksandr Dluhopolskyi, Tetiana Zatonatska, lelyzaveta Lvova, Yuriy Klapkiv

Table 4. All calls from Ukraine to countries of the world on 31 December 2017 - to 1st January 2018

\begin{tabular}{|l|c|c|}
\hline \multicolumn{1}{|c|}{ Countries } & Number & Percentage \\
\hline Russian Federation & 764,459 & 68.0 \\
\hline Poland & 106,567 & 9.6 \\
\hline Italy & 61,902 & 5.6 \\
\hline Germany & 25,309 & 2.3 \\
\hline Belarus & 23,475 & 2.0 \\
\hline Czech Republic & 16,247 & 1.4 \\
\hline United Kingdom & 12,853 & 1.1 \\
\hline France & 9,925 & 0.8 \\
\hline Moldova & 9,638 & 0.8 \\
\hline United States & 9,232 & 0.8 \\
\hline Israel & 5,638 & 0.6 \\
\hline Other & 78,959 & 7.0 \\
\hline Total & $1,124,204$ & 100.0 \\
\hline
\end{tabular}

Source: Vodafone Ukraine, 2018.

If we analyse the calls the different regions of Ukraine, it can be noted that the largest number was from the Lviv and Ivano-Frankivsk regions (13 145 and 12059 respectively), and the least - from the Donetsk and Luhansk regions (Fig. 3).

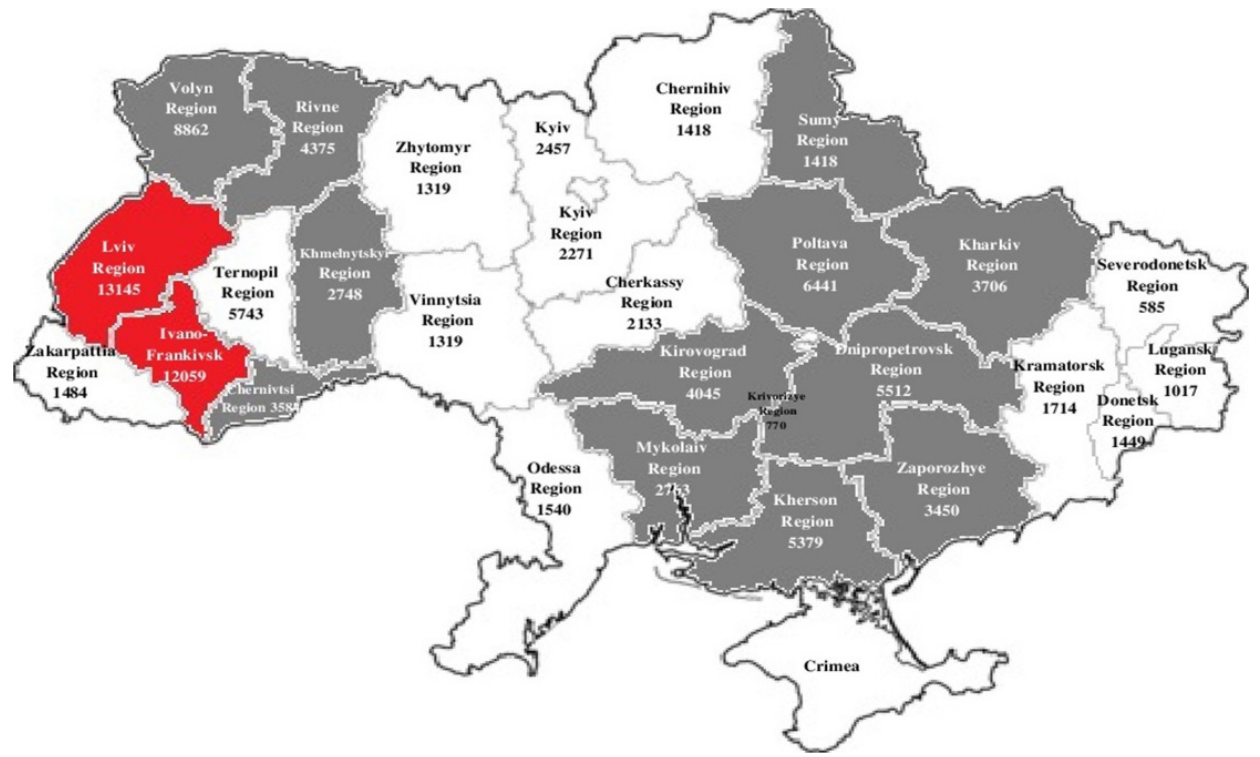

Figure 3. Number of calls from regions of Ukraine to Poland on the night of 31.12.2017 to 1.01.2018 Source: Vodafone Ukraine, 2018. 


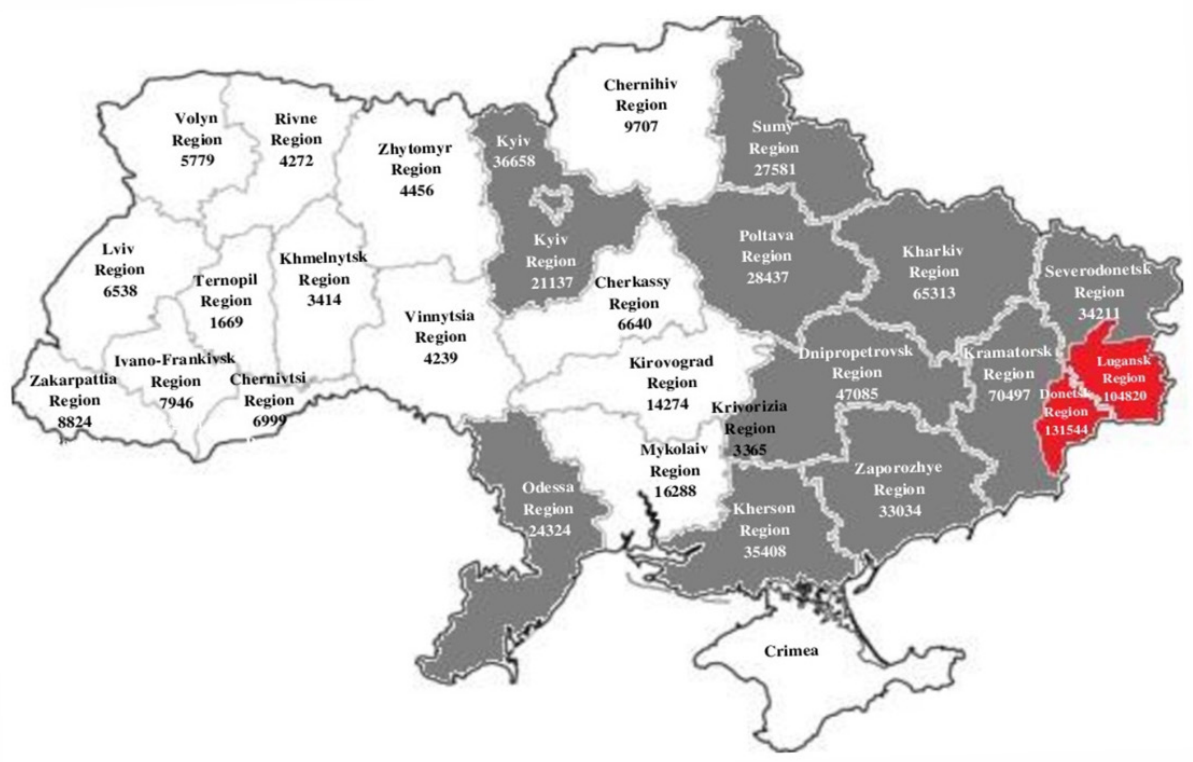

Figure 4. Number of calls from the regions of Ukraine to the Russian Federation on the night of 31.12.2017 to 1.01 .2018

Source: Vodafone Ukraine, 2018.

Fig. 4 gives an idea of the number of phone calls made with New Year greetings to Russia divided into the regions of Ukraine. It may be noted that the largest number was from the Donetsk, Luhansk and Kharkiv regions (202 041, 139031 and 65313 respectively), and the least - from the Ternopil region (1 669). However, this information should be treated with caution, as the calls were made not only to their Ukrainian migrant relatives living in Poland and Russia but also to their Polish and Russian relatives and friends.

\section{Institutional regulation of migration in Ukraine}

The issues of managing migration processes in Ukraine, and conducting and analysing statistical information are handled by the Supreme Council, the Cabinet of Ministers, the Ministry of Social Policy, research institutes at various ministries, the State Migration Service, the State Statistics Service of Ukraine, and the UN International Organisation for Migration. When investigating the actions of the state regarding the return of labour migrants to Ukraine, public policy should be considered in all these areas of activity.

While in Europe the development of normative documents on the regulation of migration flows has been actively pursued since 1949, in Ukraine, the legal basis of migration policy is framed in the Law of Ukraine "On the procedure for departure 
from Ukraine and entry into Ukraine of citizens of Ukraine" from January 21, 1994, No. 3857-XII.

The Law of Ukraine "On International Labour Migration", dated November 5, 2015, No. 761-VIII, establishes the rights of migrant workers and members of their families, contains organisational foundations for the movement, employment and social protection of citizens who work abroad, and provides for the formation and implementation of a unified state policy regarding external labour migration.

In accordance with the inherent logic of the Law (On External Labour Migration), the state policy regarding external labour migration is directed to the effective state regulation of external labour migration. In particular, it concerns the provision of the social and legal protection of labour migrants and their families, the creation of conditions for returning to Ukraine, and reintegrating labour migrants and members of their families into society. The Cabinet of Ministers of Ukraine, the central executive authorities, as well as local state administrations and local authorities formulate and implement state policy regarding external labour migration, within their powers.

The main disadvantage of this document lies in its declarative nature: it does not offer norms of direct action, merely a reference to the current legislation of Ukraine or international treaties (in 11 articles of the Law) in which there are few tools for the implementation of the declared norms. The declarative character and the lack of specificity testify to an attempt to formally implement the requirement of the Action Plan on visa liberalisation (European Commission 2018), and not an attempt to resolve specific social relations. There is also no specificity in issues concerning the return of migrants to Ukraine. Officially, migrants are provided with information about:

1. Opportunities and conditions of employment in Ukraine (but in reality, there is a lack of positive changes in the labour market, high unemployment rates, and low levels of real wages).

2. Assistance provided during economic reintegration (however, specific options for assistance and procedures for its provision are not specified in the Law).

3. The preservation of rights acquired abroad regarding social security (but the list and procedure for restoring granted rights are absent).

4. Measures to be taken to facilitate finding accommodation (however, finding a rented dwelling in Ukraine is not a critical issue, especially in large cities, but the problem is the high cost of its lease and utilities).

5. Establishing the equivalence of professional qualifications obtained abroad, as well as any examinations that need to be taken to ensure their formal recognition (although the procedure for determining qualifications exists, it is hard to access; also, the problem of applying the qualification and obtaining decent wages remains significant).

6. Establishing the equivalence of educational qualifications to allow migrant children to be admitted to school in the same class they attended in the host state, but there is no such procedure. 
On July $12^{\text {th }}, 2017$, the Cabinet of Ministers of Ukraine adopted the State Migration Strategy of Ukraine for the period from 2018 to 2025. The document provides for consideration of issues related to migration, the definition of principles, and the directions of the Strategy's implementation. One of these areas is the development of opportunities for legal temporary employment abroad, thus, raising awareness of the possibilities of migration as a way to reduce the negative effects of emigration. The strategy provides for the creation of the necessary conditions for Ukrainian emigrants to return to the Motherland, in particular:

1. A tool to provide information and consultation assistance to citizens of Ukraine returning to Ukraine through voluntary return or readmission procedures, as well as establishing cooperation with public associations for the provision of legal, psychological and other types of assistance.

2. Channels for the transfer of information to migrant workers from Ukraine, including employment opportunities and available social services in Ukraine.

3. Increasing the level of financial literacy of citizens returning to Ukraine in order for them to more effectively use their money transfers and savings for investing, or opening and developing a business.

4. The clear separation of powers and coordination of government institutions on reintegration issues.

5. A system of data collection on migrants returning to the country, including their needs for social and economic reintegration.

6. Approval of qualitative and quantitative indicators for the achievement of reintegration; prioritisation of national and regional principles.

7. National and regional (for the regions covered by the greatest mass emigration) programs for the promotion of return, with appropriate funding.

The document stems from the need to work out the issues of the possibility of introducing a state system of crediting remigrants who want to open their own business, tax benefits for those who invest money earned abroad in their own business, as well as measures aimed at supporting the adaptation of remigrant children to the domestic education system, including distance learning in Ukrainian curricula, in particular the study of the Ukrainian language abroad, and after returning, additional training programs aimed at facilitating training in Ukraine, and facilitating access to external independent evaluation.

The strategy should be implemented in two stages. The first stage covers 20182021, during which time it is planned to take measures to improve the systematic approach to managing the migration processes, to create the proper information support, and to bring national legislation into line with international standards, including in the framework of implementing commitments to the visa liberalisation regime with the European Union. The second stage (2022-2025) envisages a more purposeful use of migration and mobility tools to promote the social and economic development of the state, and also to achieve the goals of European integration.

Nevertheless, it is too early to judge the effectiveness of the approved Strategy, At this stage, the policy of reducing the outflow of the population abroad exists only 
on paper and has had no real effect, as indicators of the social and economic development of Ukraine today are far from optimal (Trading Economics 2018).

Increasing the minimum wage was also considered by the government as a factor to facilitate the return of labour migrants to Ukraine. However, there were three drastic increases in minimum wage between 2015-2017, and they had mixed consequences (Tyshchuk 2018). On the one hand, there was the "de-shadowing" of wages and the reduction in the number of people who receive the minimum wage. On the other hand, it intensified inflationary processes and increased the number of companies entering into treaties with employees as private entrepreneurs, depriving them of key social guarantees.

In general, the creation of a normative legal framework is a positive moment in the actions of the state with regard to the regulation of migration processes. However, the lack of such a policy for more than 25 years of the existence of an independent state is seen as a great challenge.

\section{Conclusions and recommendations}

Summarising the analysis of the problem of labour migration from Ukraine, we note that the key factors that make Ukrainians look for work abroad can be considered to be:

- low living standards (according to the IMF (World Economic Outlook 2017), the nominal GDP per capita in Ukraine in 2017 was $\$ 2,458$ (131st out of 186 countries in the world), while in neighbouring Poland it was $\$ 13,429$ ( $55^{\text {th }}$ place);

- high unemployment level (according to the State Statistics Service of Ukraine (2018), the load of registered unemployed for one vacancy during 2015-2017 increased from 3.8 in 2008 to 5.6 in 2017);

- high demands on workers from potential employers coupled with low wages (often employers wishing to reduce the amount of labour costs and taxes, reduce staff and give each employee the maximum number of responsibilities);

- ineffective state policy in the areas of employment and social protection of labour migrants (its mainly declarative nature).

The real conditions which would help Ukrainian migrants return permanently include:

1. The termination of hostilities. The threat to existence is a powerful argument to permanently change the place of residence and leave the country. So, as long as there is military conflict in the Eastern parts of Ukraine, there is no need to talk about the mass return of male migrants. Today, about 2.6 million Ukrainian citizens live in the territory under no control of Ukrainian authorities, and 210,000 people travel there every month, half of whom live in areas close to the conflict zone.

2. Stable economic growth and improvement of social standards. Nowadays, Social development goals are often contrary to the populist goals declared by the 
authorities. Ukraine needs further industrial development along with tax deduction for small businesses and elimination of bureaucracy in doing business, among others.

3. Expanding opportunities for small and medium-sized businesses, shifting the tax burden from small businesses to large ones, and creating new jobs. At the moment, there are doubts that large corporations owned by the oligarchs in power transparently carry out all tax deductions to the state budget. Instead, small business owners experience constant fiscal control and significant tax pressures.

4. Fighting corruption. This has remained an issue for many years, but state power still maintains the status quo in this matter, and only pressure from civil society and international organisations allows for some positive developments in anti-corruption policy.

5. Solving ecological problems. Permanent deforestation and the emission of harmful substances into the air and water worsen people's state of health and reduce the average life expectancy of the population. People with high incomes tend to provide quality living conditions for their children, and therefore they often "vote with their feet", fleeing Ukraine.

We are certain that while minimising the negative consequences of labour migration, it is necessary to eliminate the reasons that force people to emigrate. After all, if the country does not create a happy work and home life, people will inevitably leave the country in search of decent work, wages, and a higher level and quality of life. The average Ukrainian, even with a university degree, is poorly qualified. However, relatively well-paid work abroad is perceived as an ambitious mode of existence. From an economic point of view, it is clear that a person who has a certain human capital will try to obtain the greatest possible profit from it. In such a case, the only things that will stop someone from emigrating are patriotic feelings and a sense of personal responsibility for the future of his country.

\section{References}

Abbott, P., Sapsford, R. (2006), Life-Satisfaction in Post-Soviet Russia and Ukraine, "Journal of Happiness Studies", Vol. 7, Issue 2, pp. 251-287.

About External Labour Migration: The Law of Ukraine (5.11.2015 № 761-VIII). URL: http://zakon5.rada.gov.ua (accessed: 17.11.2018).

Adams, R. (2011), Evaluating the economic impact of international remittances on developing countries using household surveys: a literature review, "Journal of Development Studies", Vol. 47, pp. 809-828.

Asylum statistics. URL: http://ec.europa.eu/eurostat/statistics-explained (accessed: 17.11.2018).

Beine, M., Docquier, F., Schiff, M. (2013), International migration, transfer of norms, and home country fertility, “Canadian Journal of Economics”, Vol. 46 (4), pp. 1406-1430. 
Chauvet, L., Mercier, M. (2014), Do return migrants transfer political norms to their origin country? Evidence from Mali, "Journal of Comparative Economics", Vol. 42 (3), pp. 630-651.

Cortes, P. (2015), The feminization of international migration and its effects on the children left behind: evidence from the Philippines, "World Development", Vol. 65, pp. 62-78.

European Asylum Support Office. URL: https://www.easo.europa.eu (accessed: 17.11.2018).

European Commission Welcomed the Implementation of Ukraine Action Plan on Visa-Free Regime. URL: https://112.international/ukraine-and-eu (accessed: 17.11.2018).

Eurostat. URL: http://appsso.eurostat.ec.europa.eu/nui/setupDownloads.do (accessed: 17.11.2018).

Gibson, J., McKenzie, D., Stillman, S. (2011), The impacts of international migration on remaining household members: omnibus results from a migration lottery program, "Review of Economic Statistics", Vol. 93, pp. 1297-1318.

Human Development Report (2017). URL: http://hdr.undp.org/en (accessed: 23.10.2018).

International Migration Report (2017). United Nations Department of Economic and Social Affairs / Population Division.

International Organization for Migration. URL: http://iom.org.ua/sites/default/files (accessed: 17.11.2018).

Ivlevs, A., King, R. (2017), Emigration, remittances, and corruption experience of those staying behind, "Public Choice", Vol. 171 (3), pp. 389-408.

Ivlevs, A., Nikolova, M., Graham, C. (2019), Emigration, remittances, and the subjective well-being of those staying behind, "Journal of Population Economics", Vol. 32, pp. 113-151.

King, R. (2002), Towards a new map of European migration, "European Migration: Flows, Structures and Regulation”, Vol. 8, Issue 2, pp. 89-106.

Koshulko, O. (2015), Gender equality in case of Ukrainian female migrants in Poland, "Proceedings of the $10^{\text {th }}$ Women in Culture Conference "Gender, Culture \& Migration 2015” (Gdansk, Poland, 6-7 March)", organised by the Faculty of Social Sciences, University of Gdansk.

Lapshyna, I. (2014), Corruption as a Driver of Migration Aspirations: the Case of Ukraine, "Economics and Sociology", Vol. 7, Issue 4, pp. 113-127.

Levitt, P. (1998), Social remittances: migration driven local-level forms of cultural diffusion, "International Migration Review", Vol. 32, pp. 926-948.

Marekova, H., Balak, R., Ilavska, L., Malik, B., Szaniszlo, M., Inocent, Th., Kusin, V., Drabikova, J. (2015), Immigrants in the European Union, Backi Petrovac, Srbija, 154.

Markowska-Manista, U. (2016), The Interdisciplinary Contexts of Reintegration and Readaptation in the Era of Migration, Warsaw, 248.

Massey, D., Arango, J., Hugo, G., Kouaouci, A. (1993). Theories of International Migration: A Review and Appraisal, "Population and Development Review", Vol. 19 (3).

Migrant Integration Policy Index (2015). URL: http://www.mipex.eu (accessed: 17.11.2018). 
Migration as a Factor of Development in Ukraine, Kyiv: IOM, 2016.

Migration in Ukraine: facts and numbers, Kyiv: IOM, 2016.

Migration Policy Institute (MPI). URL: www.migrationpolicy.org/programs (accessed: 17.11.2018).

Nikolova, M., Graham, C. (2015), In transit: the well-being of migrants from transition and post-transition countries, "Journal of Economic Behaviour Organization", Vol. 112, pp. 164-186.

Nikolova, M., Roman, M., Zimmermann, K.F. (2017), Left behind but doing good? Civic engagement in two postsocialist countries, "Journal of Comparative Economics", Vol. 45 (3), pp. 658-684.

On the procedure for departure from Ukraine and entry into Ukraine of citizens of Ukraine: Law of Ukraine (January 21, 1994, № 3857-XII). URL: http://zakon5. rada.gov.ua/laws/show/3857-12 (accessed: 17.11.2018).

Piore, M.J. (1979), Birds of Passage: Migrant Labor and Industrial Societies, Cambridge, UK: Cambridge University Press.

State Border Guard Service of Ukraine. URL: https://psu.gov.ua (accessed: 17.11.2018).

The State Migration Strategy of Ukraine for the period up to 2025. URL: http://zakon2. rada.gov.ua (accessed: 17.11.2018).

State Statistics Service of Ukraine. URL: http://ww.ukrstat.gov.ua (accessed: 17.11.2018).

Trading Economics. URL: https://tradingeconomics.com/ukraine (accessed: 17.11.2018).

Trends in Total Migrant Stock: The 2015 Revision, United Nations.

Tyshchuk, T. (2018), A High Minimum Salary will Prove Individual Entrepreneurs, or Who has Become More Earned in Ukraine. URL: https://voxukraine.org/uk (accessed: 1.11.2018).

Ukraine population, 2018. URL: http://www.worldometers.info/world-population/ ukraine-population (accessed: 17.11.2018).

United Nations Treaty Collection. URL: http://treaties.un.org (accessed: 17.11.2018).

World Economic Outlook: Database-October 2017, International Monetary Fund.

Мінсоцпоітики: Понад 3,2 мільйона українців постійно працюють за кордоном. URL: https://economics.unian.ua/finance/10173092-ponad-3-2-milyona-ukrajinciv-postiyno-pracyuyut-za-kordonom-minsocpolitiki.html (accessed: 17.11.2018).

Національний банк України. URL: https://bank.gov.ua/control/uk (accessed: 17.11.2018).

Скільки українців хочуть виїхати за кордон: опитування. URL: http://kr24. com.ua/news/skilki-ukrajintsiv-hochut-vijihati-za-kordon-opituvannja (accessed: 17.11.2018). 


\section{Streszczenie}

\section{Zasady powrotu migrantów zarobkowych na Ukrainę: międzynarodowe doświadczenie i krajowe ograniczenia}

Współczesny rynek pracy na Ukrainie charakteryzuje się nie tylko wysokim poziomem bezrobocia, ale i stosunkowo niewysokim wynagrodzeniem przy rygorystycznych wymaganiach ze strony potencjalnych pracodawców. Powoduje to intensywną zarobkową migrację z Ukrainy, uwarunkowaną: niższym poziomem życia na tle państw sąsiednich; elastycznością zmiany miejsca zamieszkania i pracy; kryzysem militarnym we wschodniej części Ukrainy itp.

Artykuł poświęcony jest polityce powrotu migrantów zarobkowych na Ukrainę. Przeprowadzona analiza ilościowa ubiegających się o azyl Ukraińców w krajach europejskich od 2008 r. do 2017 r. oraz analiza podstawowych trendów migracyjnych i norm prawnych związanych z kwestiami migracji, uzasadniły niezgodność między kierunkami migracji zarobkowej Ukraińców i klasycznych migrantów. Poprzez analizę wzajemnego inspirowania tempa rozwoju człowieka i skuteczności polityki integracji migrantów, współautorzy zaproponowali kilka strategicznych narzędzi ułatwiających powrót siły roboczej na Ukrainę, które obejmują: zaprzestanie działań wojskowych, podniesienia poziomu rozwoju gospodarczego, zwalczanie korupcji, zwiększanie możliwości dla małych i średnich przedsiębiorstw oraz rozwiązywanie problemów środowiskowych.

Słowa kluczowe: obywatelstwo, kryzys, siła robocza, migracja zarobkowa, przepływy migracyjne, polityka reintegracji migrantów, polityka społeczna i gospodarcza. 